TIP Periodica Polytechnica

Social and Management Sciences

22(2), pp. 107-117, 2014

DOI: $10.3311 /$ PPSo.7673

Creative Commons Attribution (i)

\title{
Applying Goldratt's Framework to the Banking System
}

\author{
Maria Rosario A. Moreira / Julian D. M. Castaño
}

Paulo S. A. Sousa / Raquel F. Ch. Meneses

Received 22 August 2014; ACCepted After ReVISion 29 October 2014

\section{Abstract}

This paper describes the major elements of the Goldratt's framework - the Theory of Constraints (TOC) - in the banking sector, and examines the factors involved in the decision to adopt the TOC by companies in this sector. Through a deep literature review, analyzing similar cases that apply the Goldratt's framework in services and in manufacturing and the several views of its components, we aim at formulating a framework specifically for the banking system.

The study uses a qualitative methodology supported by the information extracted from reality as it is framed in a multicase study model. As part of the quantitative approach, we test several research hypotheses raised from the review of existing studies in the area.

The main factors that influence the decision to adopt the TOC are the nature and the characteristics of the banking service, the attitude towards change, the leadership and the commitment of the entire institution.

By using the Goldratt's approach outlined in this article, through the location of the constraints and develop practical measurement to facilitate the banking process improvements, banks can improve resource utilization, revenues and employee satisfaction.

\section{Keywords}

services · banking sector · Theory of Constraints · Goldratt TOC

\section{Maria Rosario A. Moreira}

Faculty of Economics, Universidade do Porto

e-mail: mrosario@fep.up.pt

Julian D. M. Castaño

Paulo S. A. Sousa

Raquel F. Ch. Meneses

Faculty of Economics, Universidade do Porto

\section{Introduction}

The Theory of Constraints is one of the most widely recognized methodologies of optimization and continuous improvement by the industry in recent years. Initially developed by Eliyahu M. Goldratt, in the 1980 s, the TOC is often used by several industrial companies worldwide, intent on the continuous improvement of their processes and increasing efficiency (Goldratt \& Cox, 1992; Mabin \& Balderstone, 2003). Several books (see, for example, Goldratt, 1990a, b, 1994, 1997, 1999, 2001; Goldratt \& Cox, 1984; Goldratt \& Fox, 1986) show his conceptual framework and ideas. Some applications and examples include Ford Motor Company, General Motors, Motorola, Pharmacia or Unilever, which have obtained positive results related to significant increases in production flow (throughput) and significant reduction in inventory, defects associated with quality, cycle time and lead time (AGI, 2012; Mabin \& Balderstone, 2003).

Several studies have shown that the general principles of the TOC can be applied to improve the performance of service organizations (e.g., Motwani et al., 1996a,b; Siha, 1999; Gupta \& Kline, 2008).

For its part, the services sector accounts for $67.01 \%$ of the gross domestic product (GDP) of the total world economy and $55 \%$ in the more developed economies (UNCTAD, 2011). In the case of the countries belonging to the OECD, the services sector has become a driving force in the growth of employment, accounting for over $70 \%$ of the current total. However, in most of these countries, productivity growth in services continues to be slow, which is why the OECD has drawn attention to the importance of adopting new policies, the use of information technologies, and innovation in products and processes, to match the countries that went through this process successfully, such as Australia and the United States (OECD, 2005).

The historical success of the TOC and the tertiary sector's need to increase its productivity serves to highlight the importance of further investigations that combine these two areas. Although there is a stark shortage of the TOC developments specifically for the sector, compared to the vast number of existing studies in industry (Bramorski et al., 1997; Ellis, 2011; Ku, 2007; 
Motwani et al., 1996a,b; Reid, 2007; Shoemaker \& Reid, 2005; Shostack, 1977; Siha, 1999), some studies related to the area have shown the relevance of and current interest in the matter, which deserves to be more fully explored from new and different perspectives, the main aim of this study. For accomplishing this main purpose, this study also aim at analyzing the literature, reviewing the different applications of the Theory of Constraints as well as the different concepts of each element of TOC: Inventory, Throughput, Operating Expenses and Constraints.

Currently, the TOC is providing a process of focusing the attention on the critical areas of improvement (Motwani et al., 1996b), and therefore has the potential for causing a much faster improvement. Another contribution for services of the TOC methodology is that it provides techniques of dealing with change (Siha, 1999).

This paper begins with a brief review of the relevant literature on the areas involved in the research (services, banking, the TOC and the TOC in services). Subsequently, the methodology used is described, followed by the results of the study. The paper ends with the conclusion, describing limitations and future topics of research.

\section{An overview of the Services concept, the Theory of Constraints and the Banking system}

A service has been defined by Kotler et al. (1986) as 'any activity or benefit that one party can give to another that is essentially intangible and does not result in the ownership of anything. Its production may or may not be tied to a physical product'.

A generic, basic and simple definition of the term was proposed by Zeithaml and Bitner (1996), which defines services as events, processes and performances. Grönroos (2007) defines them as activities that are characterized by their intangible properties, and classifies their production based on the interaction, or not, of consumers, service providers, physical resources or systems.

In addition to the intangible properties, Parasuraman et al. (1985) highlight heterogeneity as a property of services, related to the instability of the results in the production of services, which depend on a number of variables, such as service providers, the used method, and the same consumer, among others. The same authors explain the characteristic of inseparability in relation to the inability to break down the different elements that make up a service, as it is possible in the case of goods. Meanwhile, Fitzsimons and Fitzsimons (2011) state that experiences are perishable, intangible and produced by the same consumer, who necessarily becomes a co-producer. Later, Rubalcaba (2007) explains that, in addition, services are a whole dimension of activities and not just one sector, noting that the end result is achieved as a joint realization between the parties involved.

Regarding the classification of services within the existing set of proposals on the subject, this study used the classification of Schmenner (1986), as used by Siha (1999) in her study, which is considered the forerunner to the present research. The matrix classification of service processes, originally developed by Schmenner (1986), proposes four categories based on the variables of work intensity and the degree of interaction and customization: Service factory (low labor intensity and low degree of customer interaction and customization), Mass Service (high labor intensity and low degree of customer interaction and customization), Service shop (low labor intensity and high degree of customer interaction and customization), and Professional service (high labor intensity and high degree of customer interaction and customization).

\section{Banking Sector}

Within the universe of existing service organizations, the banking sector was chosen as the focus for this study, since it is extremely regulated, with little variability in processes and highly concentrated (in the European case). A specified unit of analysis (Portuguese banks) would serve as the basis for analysis, as well as allow us to extrapolate the findings. The factors that Santillan-Salgado (2011) considered as explanatory of this growth in concentration in the European banking industry are: first, the inclusion of high technology developments in banking activities and the rapid increase of competition linked to the deregulation of the sector and state intervention in times of crisis; second, the process of restructuring the EU region to achieve the creation of a single financial market in 1993; and third, the introduction of the euro from 1999, as the official currency of the majority of the EU countries.

In the Portuguese case specifically, the banking sector has been characterized by strong changes in both its structure and its system, resulting from a process of profound transformations over the last few decades: nationalization of banks in 1974, financial market liberalization in 1984, and recharged growth of competition in the sector (Canhoto, 2004). This environment, resulting from the re-privatization of the sector, required a modernization of the traditional banking institutions so that they could remain profitable and competitive in the market. Thus, the Portuguese banking sector adopted the Universal Banking model, which is characteristic of those financial institutions that are able to offer, compared to the traditional bank, a more innovative range of financial services directly or indirectly related to its core business (Bateson, 1977; Lopes, 2001; Martins, 2006).

Honoban (1999) explains how this process in Portugal, with the adoption of the universal banking model, the re-privatization of banks and the removal of limits on growth for loans (Canhoto, 2004), has endowed the Portuguese banking system with high levels of liberalism (Barth et al., 1997), being in fact one of the most drastic regulatory liberalizations in Europe (Decressin \& Mauro, 1998).

\section{The Theory of Constraints}

At the end of the 1970s, Eliyahu Moshe Goldratt developed a scheduling algorithm for industrial production known as Optimized Production Schedule (Jacobs, 1983). It was characterized 
by fixed rules and parameters designed for use in a computer program. Years later, it was named the Optimized Production Technology (OPT) (Mabin \& Balderstone, 2003).

In 1984, Goldratt published the book The Goal (Goldratt \& Cox, 1984), which explains the concepts of OPT but does not delve into the details of its implementation. This information would be the central theme of his subsequent The Race (Goldratt \& Fox, 1986), in which he developed a new system to manage the flow of material called Drum-Buffer-Rope (DRB). But it was only in 1988 that the term "Theory of Constraints" was referred to explicitly, while Goldratt listed the results of all his previous work: “(...) The second, and probably the most important result was the formulation of what I consider an overall theory running an organization. I call it Theory of Constraints and I regard everything I've done before as just a mere derivative of this theory (...)"(Goldratt, 1988). At the end of the 1980s, this theory became a tool for continuous improvement focused on processes, which, in the 1990s, would be complemented by the use of logic and Thinking Processes (TPs) as the bases for the resolution of the scenarios on which it is focused. No existing systems can have unlimited resources, because if they did, companies could increase profits without limit (Lubitsh et al., 2005; Mabin \& Balderstone, 2003; Rahman, 1998; Shostack, 1977). These authors also frame a TOC in the area of continuous improvement and define its goal as the scope of improved organizational performance.

As a systemic management philosophy, TOC is based on three interrelated premises (Schragenheim \& Dettmer, 2001):

- every system has a goal and a set of necessary conditions that must be satisfied if its goal is to be achieved;

- the overall system's performance is more than just the sum of its component performances; and

- very few factors or constraints, often only one, limit a system's performance at any given time.
Among the variety of concepts involved in this theory and the extension of the philosophy on which it is based, the term 'restriction' is established as the starting point for the whole philosophy of the TOC. In the same publication that first referenced the TOC, Goldratt (1988), p. 453, defines a constraint as "anything that limits a system from achieving higher performance versus its goal". Regarding performance measurement systems, and based on the assumption that the goal of any business is to generate money, he defines three TOC indicators (Goldratt, 1992): throughput (T) is the rate at which the system generates money associated with sales; inventory (I) is the money invested in the system to generate the Throughput; and Operating Expenses (OE) is the money the system spends in turning inventory into throughput (Mabin \& Balderstone, 2003; Motwani et al., 1996a; Shostack, 1977). Although these measures are different from traditional measures, they can be converted to more traditional measures with simple mathematical operations (Finch \& Luebbe, 1995). For example: Net profit $=$ throughput \pm operating expense; Inventory turns $=$ throughput /inventory; Productivity = throughput /operating expense.

For most service businesses, throughput and operating expenses are appropriate measures. However, inventory, as defined above, may not be appropriate for all service businesses.

The elements of TOC structure can be associated to three groups (see Fig. 1). In the category of Logistics is one of the leading and most used TOC contributions since its inception: the process of targeting the five steps. It is an instrument that seeks to be a methodology for managing the constraints. In this same group is the DRB (Drum-Buffer-Rope) programming system, mentioned above, which seeks to exploit the system to get maximum performance from the detection of the constraint and the actual amount of resources and thus obtaining a dramatic improvement in TOP performance indicators (Motwani et al., 1996a; Reid, 2007; Siha, 1999). To complete this group we have

\begin{tabular}{|c|c|c|c|c|c|c|c|c|}
\hline \multicolumn{9}{|c|}{ THEORY OF CONSTRAINTS } \\
\hline \multicolumn{3}{|c|}{ Logistics } & \multicolumn{3}{|c|}{ System Performance } & \multicolumn{3}{|c|}{ Problem Solving / Thinking Processes } \\
\hline $\begin{array}{l}\text { Five-step } \\
\text { focusing } \\
\text { process }\end{array}$ & $\begin{array}{l}\text { Scheduling } \\
\text { process }\end{array}$ & $\begin{array}{l}\text { VAT } \\
\text { analysis }\end{array}$ & $\begin{array}{l}\text { TOC indica- } \\
\text { tors: } \\
\text { Throughput } \\
\text { Inventory } \\
\text { Operating } \\
\text { Expense }\end{array}$ & $\begin{array}{l}\text { Product mix } \\
\text { decisions }\end{array}$ & $\begin{array}{l}\text { Throughput } \\
\text { Dollar Days } \\
\text { Inventory Dollar } \\
\text { Days }\end{array}$ & ECE Diagrams & $\begin{array}{l}\text { ECE } \\
\text { Audit }\end{array}$ & $\begin{array}{l}\text { Cloud Dia- } \\
\text { grams }\end{array}$ \\
\hline & $\begin{array}{l}\text { Drum-Buffer } \\
\text { and Rope }\end{array}$ & & & & & $\begin{array}{l}\text { Current reality } \\
\text { tree } \\
\text { Negative } \\
\text { branch } \\
\text { Future reality } \\
\text { tree } \\
\text { Prerequisite } \\
\text { tree } \\
\text { Transition tree }\end{array}$ & & \\
\hline
\end{tabular}

Fig. 1. Structure of TOC (adapted from Inman et al. (2009)) 
the VAT analysis, a classification model of production plants based on the amount of their products (Siha, 1999). In the second group we have the System performance indicators (Mabin \& Balderstone, 2003; Motwani et al., 1996a; Siha, 1999). Finally, the third group Problem Solving / Thinking Processes covered by the audit, the diagrams of effect-cause-effect (ECE) and the cloud diagrams as test media from logical thinking in the search for the answers to the questions: What changed? Why change? and how to make that change? (Ku, 2007; Reid, 2007; Shoemaker \& Reid, 2005; Taylor \& Thomas, 2008)

\section{Applying the Theory of Constraints in Services: a review}

TOC is a theory created mainly for industrial process optimization (Davies et al., 2005; Gillespie et al., 1999; Ku, 2007; Mabin \& Balderstone, 2003; Motwani et al. 1996a,b; Reid, 2007; Shostack, 1977; Siha, 1999; Spencer, 2000). The terminology used, its indicators, the tools for managing problems, the kind of thinking, their premises and, in general, all elements involved, were developed according to the specific characteristics of the processes to transform raw material into tangible products (Ellis, 2011; Shostack, 1977; Siha, 1999).

Subsequent to the success of this methodology in the secondary sector and the increasing prominence of the service sector in the world economy, the idea arose of extending the application of the TOC beyond traditional borders for which it had been designed (Motwani et al. 1996a,b). Adelman (1991) reported one of the early applications of TOC to service (application of the drum-buffer-rope to a donut shop). Table 1 systematizes the TOC literature with relevance to services.

With respect to the relevant literature, as seen in Table 1, the first countries to publish studies on the application of TOC in various areas within the services sector were the United States, England, Australia and Israel, demonstrating the effectiveness of this philosophy in other areas besides the industrial one. Although in recent years the literature related to the topic has significantly increased, the approaches are still too incipient to match the large number of studies on TOC developed for industry (Ellis, 2011; Motwani et al., 1996a,b; Reid, 2007).

Based on the three elements (services sector, banking sector and the TOC) and as a result of the analysis of the information extracted from the literature analyzed, this paper aims to, firstly, examine the implementation of the Theory of Constraints in the banking sector, and, more specifically, the main TOC concepts (inventory, throughput, operating expenses and constraints), based on the model to implement TOC for service organizations (Shostack, 1977) and the study of the application of TOC in banks (Bramorski et al., 1997).

In fact, the research of Bramorski et al. (1997) was the first one to show how banks can apply the principles of constraint management to improve their processes to obtain competitive advantage. However, it was made using a single bank example and not testing the importance of the several factors. Later on, Reid (2007) proposed a five-step sequential process for implementing the TOC concepts. The approach is mainly descriptive and only an example is used to illustrate the framework. Therefore, further studies on the main performance indicators for specific services would be relevant, as they would facilitate the search for more effective solutions to typical problems of these services.

Next, an analysis is conducted of the factors involved in the decision to adopt TOC by companies in the banking sector, as supported in the literature review.

\section{Methodology}

This research can be considered a mixed study inspired by the different approaches and methodologies that were identified during the literature review on the TOC in services. In Table 1 we can see the methodology used in several studies.

\section{Research design}

Initially, the study uses a qualitative methodology with a strong theoretical component and puts forward a proposal for posterior quantitative validation.

Given the lack of specific literature on the subject, this first theoretical approach is supported by the information extracted from reality through different instruments and it is framed in a multi-case study model. This approach provided the opportunity to include triangulation as a method aimed at achieving accuracy, precision and objectivity in answering the research question. As part of the quantitative, Table 2 presents the research hypotheses raised from the review of existing studies in the area.

The total number of hypotheses are grouped into three categories according to the affinity of the issues that each addresses. They involve some degree of influence on the decision to adopt TOC, based on the level of current development of TOC for application in the banking sector $(\mathrm{H} 1)$, the nature and characteristics of banking services (H2), and the internal management of sector institutions (H3).

\section{Procedure}

Given the urgent need to increase productivity and optimize their processes to meet the many challenges that the global economy imposes, the banking sector was selected as the focus for this research. In addition, this sector remains highly regulated, and its operations and services have less variability among the institutions that compose it.

Portuguese banks were chosen as the unit of analysis. With regard to the complete sample, the Bank of Portugal (BP) has records of 36 legally constituted and recognized banks, of which 24 are members of the Portuguese Association of Banks (APB), representing $94 \%$ of the banking system's total assets ("APB," 2012; "BP," 2012). Given the default profile for the study, banks that are highly specialized business units of other banks, without participation in the commercial banking market 
Tab. 1. Theory of constraints in services: Literature review

\begin{tabular}{|c|c|c|c|c|}
\hline \multicolumn{5}{|c|}{ Theory of Constraints in Services } \\
\hline Authors & Country & Type & Sector & Objectives \\
\hline Goldratt \& Weiss (2005) & Israel & \multirow{15}{*}{$\begin{array}{l}\text { oे } \\
\stackrel{D}{D} \\
0 \\
\infty \\
\infty \\
0 \\
0\end{array}$} & Education & $\begin{array}{l}\text { The applying TOC to improve the quality of school education and } \\
\text { productivity }\end{array}$ \\
\hline Spencer \& Wathen 1994 & \multirow[b]{2}{*}{ UK } & & Furniture & Improving the performance of order entry process of the company \\
\hline $\begin{array}{l}\text { Ritson \& Waterfield } \\
\qquad(2005)\end{array}$ & & & Health - Consulting & $\begin{array}{l}\text { To modernize mental health services of the UK population through the } \\
\text { merger of the only two service providers. }\end{array}$ \\
\hline Adelman (1991 & \multirow{13}{*}{ USA } & & \multirow{2}{*}{ Food } & $\begin{array}{l}\text { To evaluate the implementation, benefits and feasibility of TOC as a tool } \\
\text { for planning and control of production in the service. }\end{array}$ \\
\hline Spencer (2000) & & & & $\begin{array}{l}\text { To evaluate the possibility of the application of the principles of TOC to } \\
\text { both the accounting and the production systems at a donut shop. }\end{array}$ \\
\hline $\begin{array}{l}\text { Tanner \& Honeycutt } \\
\text { (1996) }\end{array}$ & & & Re-engineering & $\begin{array}{l}\text { To describe the application of TOC philosophy to analyse workforce } \\
\text { process, identify the bottleneck and eliminate them }\end{array}$ \\
\hline $\begin{array}{l}\text { Motwani \& Vogelsang } \\
\qquad(1996)\end{array}$ & & & Construction & $\begin{array}{l}\text { Support improved performance and productivity of the delivery of the } \\
\text { service provided by the company. }\end{array}$ \\
\hline $\begin{array}{l}\text { Motwani et al. (1996a) } \\
\text { Motwani et al. (1996b) }\end{array}$ & & & \multirow[t]{2}{*}{ Health } & $\begin{array}{l}\text { Application of TOC for optimization and increased productivity of } \\
\text { nonprofit organizations. }\end{array}$ \\
\hline Gupta \& Kline (2008) & & & & Improving performance indicators identified in the system TOC. \\
\hline Olson (1998) & & & Alarms & $\begin{array}{l}\text { To discusses how exploiting a system's constraint via reducing the batch } \\
\text { size helps in increasing the performance of a business. }\end{array}$ \\
\hline Gillespie et al. (1999) & & & Unspecified & $\begin{array}{l}\text { Study the impact of TOC concepts in administrative functions, applying } \\
\text { performance indicators. }\end{array}$ \\
\hline Reid \& Cornier (2003) & & & Restaurants & $\begin{array}{l}\text { To evaluate the possibility of the successful use of TOC TP tools to } \\
\text { improve the performance of a small business. }\end{array}$ \\
\hline $\begin{array}{l}\text { Shoemaker \& Reid } \\
\text { (2005) }\end{array}$ & & & Public Services & $\begin{array}{l}\text { To consider using TOC TP in a public service organization for service } \\
\text { and optimization of the processes. }\end{array}$ \\
\hline Reid (2007) & & & Banking & $\begin{array}{l}\text { To improve credit approval processes and overcome the constraints of } \\
\text { the system. }\end{array}$ \\
\hline Taylor \& Thomas (2008) & & & Consultancy & $\begin{array}{l}\text { Improving the performace of billing system for increased business } \\
\text { productivity. }\end{array}$ \\
\hline Siha (1999) & & 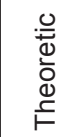 & Service Sector & $\begin{array}{l}\text { To create a classification model for implementing TOC in different } \\
\text { service organizations. Adequacy of vocabulary TOC to services and } \\
\text { developing solutions to potential problems TOC. }\end{array}$ \\
\hline López et al. (2006) & Columbia & $\geq$ & Health & $\begin{array}{l}\text { To describe the public hospitals' current situation, gives a startegy } \\
\text { form resolving the problem so detected and formulates a practical and } \\
\text { systematic application for correcting it }\end{array}$ \\
\hline Bramorski et al. (1997) & Australia & $\frac{0}{\frac{0}{\pi}}$ & Banking & $\begin{array}{l}\text { A classified model for Applying the Theory of Constraints to Service } \\
\text { organizations. }\end{array}$ \\
\hline Davies et al. (2005) & $\begin{array}{l}\text { Australia } \\
\text { / New } \\
\text { Zelanda }\end{array}$ & யิ & $\begin{array}{l}\text { Operational } \\
\text { Research / Manage- } \\
\text { ment Science }\end{array}$ & $\begin{array}{l}\text { To study TOC TP tools in relation to traditional methodologies Or / MS } \\
\text { for building multi methodological tools. }\end{array}$ \\
\hline
\end{tabular}

or institutions without a minimum component of the universal banking concept, were excluded from the study. 24 banks were contacted via direct mail, e-mail and telephone in order to request their participation in the study. Following these contacts, four banks agreed to participate in the multi-case study. A fifth bank was included in the quantitative study, but it decided to participate only in the interview (and not in the questionnaire) due to time restrictions and internal priorities.

For the study of this sample, and according to the methodologies referred to when defining their aims, three tools were used for data collection. To develop the multi-case study model, semi-structured personal interviews with predefined questions and issues were used. The interview script is divided into six sections (characterization of the interviewee, the bank, inventory, throughput, operating expenses and constraints), grouping 30 questions designed from the findings of the studies by Bramorski et al. (1997) and Siha (1999). Also within the qualitative component, a tool was constructed in a matrix format, confronting the bank list for the Universal Banking model (Fitzsimons \& Fitzsimons, 2011) with the four categories of 
Tab. 2. Research hypotheses

Research Hypothesis

Author

H1: The level of development of TOC for application in the banking sector negatively influences their adoption by the banking sector.

H1.1: The existence of TOC indicators for services influences the application of this theory $\quad$ Bramorski et al. (1997)

in the banking sector.

Motwani et al. (1996b)

H1.2: The existence of TOC vocabulary for services influences the decision to adopt this

theory in the banking sector.

Bramorski et al. (1997)

Spencer (2000)

H1.3: The existence of a formal method for implementing TOC in services influences their application in the banking sector.

$\mathrm{H} 1.4$ : TOC is not a recognized tool in the banking sector.

Ellis (2011); Motwani et al. (1996b); Reid (2007)

Exploratory

$\mathrm{H} 2$ : The nature and characteristics of banking services hinder the adoption of TOC by the banking sector

$\mathrm{H} 2.1$ : The difficulty in determining the restrictions on the banking processes, negatively

influences the adoption of TOC in the banking.

Bramorski et al. (1997); Motwani et al.

(1996b); Reid \& Cornier (2003)

H2.2: Creating TOC as a unique tool for the industrial sector, negatively influences their adoption by the industry.

$\mathrm{H} 2.3$ : The particular characteristics of the services are crucial to the decisions to apply

TOC in the banking sector.

Spencer (2000)

Reid (2007)

$\mathrm{H} 2.4$ : The nature of restrictions on services difficult to detect and thus, negatively influenc-

es the decision apply TOC in banking sector.

Ellis (2011); Reid (2007); Siha (1999);

Spencer (2000)

Bramorski et al. (1997); Reid (2007); Reid

\& Cornier (2003)

H3: The adoption of TOC in the banking sector depends on the internal management of sector institutions.

H3.1: The organizational commitment of banking institutions determines the success of the

application of TOC in the sector.

Bessant et al. (2001)

Gupta \& Kline (2008)

$\mathrm{H} 3.2$ : Resistance to change in the organization, hinders the implementation of TOC in

banking sector companies.

Ritson \& Waterfield (2005) Taylor III \&

Thomas (2008)

H3.3: The adoption of TOC in banks depends on motivation and leadership generated by

management.

Bessant et al. (2001)

Ritson \& Waterfield (2005)

H3.4: The innovative culture of the bank determines the adoption the adoption of TOC to

optimize their processes.

H3.5: The absence of systematic and disciplined processes in the banking companies, hinders the application of TOC in improving their processes

H3.6: Banks do not have a formal policy of continuous improvement.

Reid \& Cornier (2003); Gupta \& Kline

(2008); Spencer (2000)

Reid \& Cornier (2003); Taylor III \& Thomas (2008)

H3.7: Banks do not consider that their systems are limited and, therefore, they do not con-

sider the need for the use of tools such as TOC.

H3.8: Professional skills of banking employees determine adoption of TOC.

Exploratory

Rahman (1998)

H3.9: The bank management provides the resources needed to drive continuous

improvement programs.

Exploratory

Bessant et al. (2001)

services proposed by Schmenner (1986), which reinforced the information obtained in the interviews, in the literature and allowed the gathering of details of the TOC elements within the Schmenner's model. Four interviews were conducted in total (two in Lisbon and two in Porto) to high hierarchical level staff, corresponding to the commercial administration, management control and process improvement supervision.

Regarding the analysis of the determinants of adopting TOC by banks, which corresponds to the quantitative component of the study, we used an online survey format with 26 questions directly related to the research hypotheses presented in Table 2. This questionnaire was subject to a pre-test with two professionals in the area of continuous process improvement and the services sector, a statistician and a director of continuous improvement in a bank. 41 responses were obtained from banking employees from the five banks involved in the study, which are directly related to these institutions' area of continuous improvement and process optimization (51.3\% response rate).

\section{Results and discussion}

The results analysis is divided into 2 parts: the multi-case analysis and the statistical analysis.

\section{Multi-case analysis}

The multi-case study clearly showed that there are four main factors present in the dynamics of the current banking sector, also highlighted in the responses of the banks participating in the characterization of the TOC for the services sector. These are: the importance of technology resources and information systems, the need to increase the quality of their services, the use of human resources, and the current economic situation. Our findings are in line with Ramachandran and Chidambaram (2012), that stressed 
that the quality of the service in bank systems is vital for their success, considering that the customers are the most valuable asset of any organization.

For the banks participating in the multi-case, the four elements of the Theory of Constraints are defined and measured as:

- Inventory: money invested in the system to guarantee the Throughput.

- Technological resources used and developed;

- Human resources education and training;

- Increased efficiency (outsourcing and risk management);

- Commercial area (back office and front office) and distribution channels (physical and virtual);

- Throughput: rate at which the system generates money associated to sales.

- Service sales as housing loans, trading, deposits and other commissions;

- Performance of human resources (commercial area);

- Increase efficiency (Expense rationalization, resources and process optimization, quality);

- Customer relationship (knowledge, proximity, flexibility, satisfaction);

- Operating Expenses: the money the system spends in turning Inventory into Throughput.

- Distribution channel management (physical and virtual);

- Human Resources management;

- Information technologies and systems development;

- Constraints: anything that limits the system for achieving higher performance versus its goals.

- Insufficient technological resources and financial capital to solve;

- Economic situation;
- Regulations and governmental control, working processes and organizational structure (design, current status, efficiency, costs).

The detailed results of the multi-case analysis can be followed in Castaño et al. (2013).

\section{Statistical analysis}

With regard to the sample, it is observed that most of the banking employees surveyed $(75.6 \%)$ have a bachelor's degree, followed by those with completed secondary education $(17.1 \%)$. The remaining percentage is distributed among staff with a master's degree (4.9\%) and those who have no degree $(2.4 \%)$.

With respect to knowledge and use of continuous improvement tools, Fig. 2 shows that Lean Manufacturing is widely recognized among staff respondents $(53.7 \%)$ that also have reported having knowledge about its use in the bank (51.2\%). The other better known tools are Statistical Process Control and 6 Sigma (34.1\% and 31.7\% respectively) and percentages regarding its implementation $(24.4 \%$ and $9.8 \%$ respectively). In the specific case of TOC, it is seen that it is one of the least recognized tools among staff surveyed with $7.3 \%$, being surpassed only by Total Productive Maintenance with $4.9 \%$.

Moreover, respondents were asked whether, in addition to recognizing the existence of the theory of constraints as an optimization tool, they knew in detail the proposed philosophy. Only $22 \%$ answered affirmatively, and only $2.4 \%$ said that the bank had ever tried to implement it. Thus, the responses of these bank workers are related to one of the assumptions proposed by this exploratory study, validating that, for participating banks, the lack of the TOC knowledge could intervene in the decision to adopt it.

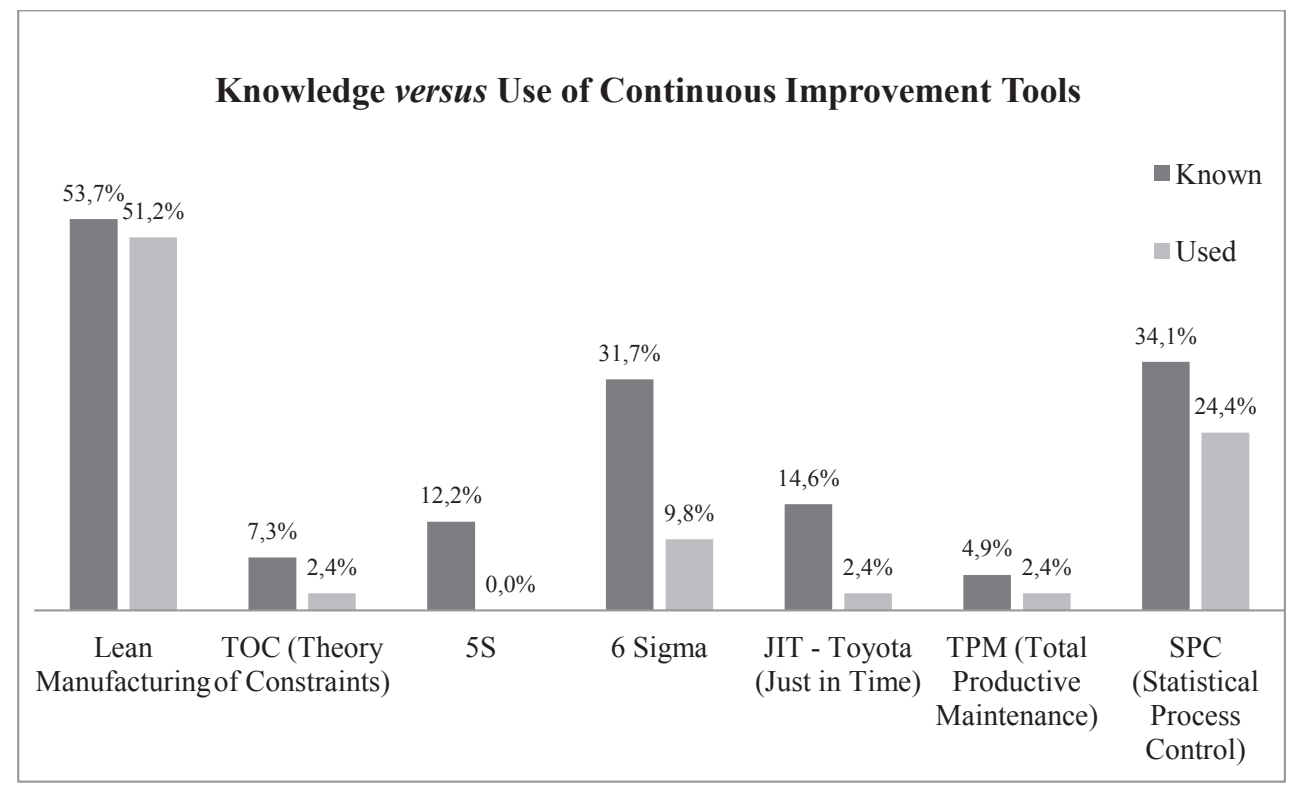

Fig. 2. Knowledge and use of continuous improvement tools 
It was also considered important to ask their position about the availability/scarcity of resources (not only financial) to drive continuous improvement programs, as it is an important factor in the decision of adopting the TOC according to Bessant et al. (2001). $36 \%$ of respondents said that these programs are usually developed by the internal structure of the bank for its own use and only $2.8 \%$ is exclusively adopting continuous improvement programs. Nevertheless, there is a clear commitment to the implementation of new tools for process optimization by banking organizations.

Concerning the hypotheses validation, Table 3 and Table 4 show the results of the tests performed on the hypotheses presented in Table 2.

For analyzing the hypotheses, we employed two different statistical tests: the Binomial test and the McNemar test. For hypothesis $\mathrm{H} 1, \mathrm{H} 2$ and $\mathrm{H} 3.6$, as we want to assess if the categories defined by the corresponding variables occur with a probability of $50 \%$, we employed the Binomial test. We consider statistically significant the tests with a $p$-value $\leq \alpha=0,05$ (Table 3). For hypotheses H3.1. to H3.4 and H3.8, we use the McNemar test, that is an appropriate nonparametric test for when the variables are dichotomic and we want to test the null hypothesis that there is equality between the proportions of two dependent samples. Again, we consider statistically significant the tests with a $p$-value $\leq \alpha=0,05$ (Table 4).

The statistical analysis shows that, globally, the claims made by the relevant theory are also present in the reality of Portuguese banks. In countries identified in the literature as pioneers in the study and application of the TOC in services (USA and UK), the level of development of the TOC for this sector is still classified as too young to spread in the same way as it did in the processing industry. Since its inception in 1980, the Theory of Constraints has evolved with the goal of becoming a highly efficient tool for optimizing the industrial sector; however, the existing theory does not verify the same trend in the tertiary sector. Based on this fact, it was expected that the level of development of the TOC for services would influence banking sector companies to adopt this tool and make wide use of it in the financial business. The importance of the specific factors that support this claim $(\mathrm{H} 1.1$ : Existence of indicators, H1.2: Existence of vocabulary, H1.3: Existence of a specific implementation method) was confirmed in the Portuguese banking reality. The importance of the specific factors that support this claim (H1.1: Existence of indicators, H1.2: Existence of vocabulary, H1.3: There is a specific implementation method) was confirmed in the Portuguese banking reality. However, it should be noted that, according to the responses from the banking employees surveyed, the majority $(88.9 \%)$ attributed greater influence to the existence of a deployment method (Ellis, 2011; Motwani et al., 1996b; Reid, 2007), while also recognizing the intervention of the other two. Regarding H1.4, it was observed that TOC is one of least well known continuous improvement tools among the banking employees surveyed with $7.3 \%$, being surpassed only by Total Productive Maintenance with $4.9 \%$.

Tab. 3. Results of hypothesis tests (H1, H2 and H3.6)

\begin{tabular}{|c|c|c|c|}
\hline \multicolumn{4}{|c|}{ Binomial Test Results } \\
\hline \multicolumn{2}{|c|}{ Hypothesis } & $p$-value & Decision \\
\hline \multirow{3}{*}{$\mathrm{H} 1$} & H1.1 & 0.000 & Reject \\
\hline & $\mathrm{H} 1.2$ & 0.000 & Reject \\
\hline & $\mathrm{H} 1.3$ & 0.018 & Reject \\
\hline \multirow{3}{*}{$\mathrm{H} 2$} & $\mathrm{H} 2.1$ & 0.002 & Reject \\
\hline & \multirow{2}{*}{$\mathrm{H} 2.2$} & 0.000 & Reject \\
\hline & & 0.532 & Retain \\
\hline $\mathrm{H} 3$ & H3.6 & 0.000 & Reject \\
\hline
\end{tabular}

Also related to the design of the TOC according to industry, Parasuraman et al. (1985) stated that the characteristics of services (intangibility, inseparability, heterogeneity and perish ability) should be carefully studied and taken into account when pursuing research in the area, as they are the conditions that make a significant difference between a service and product. Therefore, the fact that the TOC has been designed to interact with characteristics totally contrary to those who own services clearly increases the challenge and, in turn, minimizes the intention of banks to try it. Based on the above, it was not

Tab. 4. Results of hypothesis tests (H3.1, H3.2, H3.3, H3.4 and H3.8)

\begin{tabular}{|c|c|c|c|c|c|c|c|c|c|c|c|c|}
\hline \multicolumn{13}{|c|}{ McNemar Test Results } \\
\hline & \multicolumn{2}{|c|}{ H3.1 } & \multicolumn{2}{|c|}{ H3.2 } & \multicolumn{2}{|c|}{ H3.3 } & \multicolumn{2}{|c|}{$\mathrm{H} 3.4$} & \multicolumn{2}{|c|}{ H3.5 } & \multicolumn{2}{|c|}{ H3.8 } \\
\hline & $p$-value & Decis. & $p$-value & Decis. & $p$-value & Decis. & $p$-value & Decis. & $p$-value & Decis. & $p$-value & Decis. \\
\hline H3.1 & & & 0.007 & Reject & 1 & Retain & & & 0.078 & Retain & 0.000 & Reject \\
\hline H3.2 & 0.007 & Reject & & & 0.001 & Reject & & & 0.424 & Retain & 0.000 & Reject \\
\hline H3.3 & 1 & Retain & 0.001 & Reject & & & & & 0.041 & Reject & 0.008 & Reject \\
\hline $\mathrm{H} 3.4$ & & & & & & & 0.117 & Retain & & & & \\
\hline H3.5 & 0.078 & Retain & 0.424 & Retain & 0.041 & Reject & & & & & 0.000 & Reject \\
\hline
\end{tabular}


surprising to corroborate that the nature and characteristics of services (banking services in this case) are also involved in the decision to implement the TOC by Portuguese financial institutions (H2). Specifically, it was found that the fact that the TOC has been created in the industrial context has also some degree of influence on whether to adopt it (H2.2), and that the degree of difficulty to detect restrictions on banking processes has a negative influence on the adoption of the TOC (H2.1). The restrictions associated with service delivery systems (regulations, policies, measures, etc.) differ from those of typical industry (physical nature), i.e., being self-imposed and intangible, and they are thus difficult to clearly identify by bank management. With regard to the influence related to the difficulty in detecting the restrictions on services (H2.4), 61\% of the population surveyed recognized that there was a "medium" degree of difficulty in identifying the real factors that limit the bank's processes, $24.4 \%$ consider it as "easy", while 14.6\% reported feeling a "high difficulty". From the above, it should be noted that recognizing the existence of some degree of difficulty in detecting the restrictions by the respondents in this study could also be a determining factor in the behavior of these banking institutions regarding the use of the TOC.

Finally, despite being a statement reiterated by the literature, the responses of the Portuguese banking employees did not allow us to confirm, in general, that bank management is a factor in the adoption of the TOC. In fact, $80.6 \%$ of the respondents reported feeling that their bank is committed to the implementation of continuous improvement tools; however, only $2.4 \%$ reported knowing that the TOC had been implemented, a situation that reinforces the independence of these two events (the bank's management and the decision to adopt TOC). However, the results indicate that there are specific factors within management which could become crucial in deciding to implement TOC, such as organizational commitment in implementing continuous improvement programs (H3.1), the attitude towards change (H3.2), motivation and leadership (H3.3), and existence of systematic processes (H3.5).

When relating academic background with knowledge of this instrument (H3.8), the results show that the recognition of the TOC is concentrated among graduate banking employees $(77.18 \%)$ in areas related mainly to management $(50 \%)$, the remainder being distributed in areas of economics, information technology or marketing. Finally, it was considered important to determine the position of the banks on the availability of resources (not only financial) to drive continuous improvement programs, a crucial factor in the decision to adopt the TOC according to Bessant et al. (2001). It is observed that $82.9 \%$ of the respondents recognize the existence of departments dedicated to the implementation of continuous improvement programs to operate processes within the structure of these banks, $36 \%$ of respondents stated that these programs are usually developed by the internal structure of the bank for its own use, $2.8 \%$ state that only existing continuous improvement programs are adopted, and $61 \%$ use both strategies.

\section{Conclusion}

This study proposed a characterization of the main TOC elements (Inventory, Throughput, Operating Expenses and Constraints) according to the different types of services defined by Schemenner (1986) and based on studies by Bramorski et al. (1997) and Siha (1999). It was found that these TOC elements in banking are closely linked to four factors identified in the current global financial sector and in Portuguese banks, which could also influence the results of the multi-case study used in reaching this goal. These are: The importance of technological resources and information systems, the need to increase the quality of their services, the use of human resources, and the current economic situation.

Through the quantitative component of the data analysis performed in this study, we analyzed, for the reality of the Portuguese banking sector, the factors considered by the theory as determinants for organizations to adopt the TOC as one of their continuous improvement programs. Based on the responses from the Portuguese banking employees, it was concluded that the current development of the TOC for services, and specifically for banking, is still insufficient to enable those companies to include it in their management. It was also possible to infer that the nature and characteristics of services is another factor which greatly limits the adoption of TOC by banks, as their particular properties make their associated restrictions more difficult to identify. Within this aspect, it was also possible to validate that, given the fact that the TOC emerged from within the industrial sector, the Portuguese banking organizations are suspicious of adopting this management tool. Unawareness of the existence of this tool beyond the boundaries of the industry could be one of the strongest obstacles to its spread and development in other fields.

Although the literature has noted that the management of these companies is influential on the decision to adopt the TOC, the sample did not confirm this assumption. Specifically, some elements in the management of these organizations are crucial in this decision (commitment, attitude towards change and organizational leadership). However, some could not be confirmed (the innovative culture of the company) and others could not be part of the inferential statistical analysis due to the behavior of the responses. The process of this research and the results obtained were somewhat limited, mainly due to the reluctance of most active banks in Portugal to participate in the study. Furthermore, and considering that one of the advantages of conducting personal interviews is the possibility of examining the interviewee responses through additional factors, not only by consciously transmitted information (Saunders et al., 2003), it was possible to detect that some of the banking employees interviewed refrained from responding, with details 
and faithfully, to questions they considered compromising the bank's privacy.

A topic for future research could be to focus on determining which of factors are more or less influential on the decision to adopt banking TOC. In this case, the fidelity of the process and results should be safeguarded, with more time for the development of the study, a broader number of participating banks and responses to the questionnaires. With regard to the characterization of the TOC in the sector, having only done a first exploratory approach (corresponding to qualitative multi-case study), the proposal is to compare these results with the reality of the banking sector overall, using the inferential statistical validation techniques similar to those used in the quantitative component of this research.

\section{Acknowledgements}

The authors wish to acknowledge the anonymous reviewer for his/her detailed and helpful comments to the manuscript.

\section{References}

Adelman P. J. (1991) Applying Theory of Constraints in a Service Environment: A case Study of Performance. Measurement and Manufacturing. A Collection of TOC Results.

AGI Overview of Results. Goldratt Institute, http://www.goldratt.com/. Accessed on 26th Sept. 2012.

APB Associados Associação Portuguesa de Bancos. http://www.apb.pt/ associados accessed on 11th March 2012

Barth J. R., Nolle D. E., Rice T. N. (1997) Commercial banking structure, regulation, and performance: an international comparison. Managerial Finance, 23(11), pp. 1-39. DOI: $\underline{10.1108 / \mathrm{eb} 018653}$

Bateson J. (1977) "Do we need service marketing? Marketing consumer services: new insights", report 75-115. Marketing Science Institute, Boston.

Bessant J., Caffyn S., Gallagher M. (2001) An evolutionary model of continuous improvement behaviour. Technovation, 21(2), pp. 67-77. DOI: $10.1016 / \mathrm{s} 0166-4972(00) 00023-7$

BP Instituições Autorizadas Banco de Portugal. http://www.bportugal. $\mathrm{pt} / \mathrm{pt}-\mathrm{PT} /$ Supervisao/Paginas/ Instituicoesautorizadas.aspx\#anchor. accessed on 15th Sep. 2013

Bramorski T., Madan M., Motwani J. (1997) Application of the Theory of Constraints in Banks. The Bankers Magazine, Enero-Febrero, pp. 53-59.

Canhoto A. (2004) Portuguese banking: A structural model of competition in the deposits market. Review of Financial Economics, 13 (1), pp. 41-63.

Castaño J. D., Moreira M. R., Sousa P. S., Meneses R. F. C. (2013) Theory of Constraints in the Service Sector: Characterization for Banking and Analysis of the Factors Involved in Its Adoption. Lecture Notes In Business Information Processing, 143, pp. 58-72. DOI: 10.1007/978-3-642-36356-6_5

Davies J., Mabin V. J., Balderstone S. J. (2005) The theory of constraints: a methodology apart? - a comparison with selected OR/MS methodologies. Omega, 33 (6), pp. 506-524. DOI: 10.1016/j.omega.2004.07.015

Decressin J., Mauro P. (1998) The Portuguese banking system: Feeling its pulse on the eve of EMU membership. IMF Country Report, 98, p. 127.

Ellis S. C. (2011) A Theory of Constraints Service Systems Improvement Method: Case of the Airline Turnaround Problem. Doctoral dissertation, Florida International University.

Fitzsimons, J. A., Fitzsimons, M. J. (2011) Service management: Operations, strategy, and information technology. Boston, MA: McGraw-Hill.

Gillespie M. W., Patterson M. C., Bob, H. (1999) TOC Beyond Manufacturing. Industrial Management, 41 (6), pp. 22-25.
Goldratt E. M., Cox J. (1992) The Goal. 2nd Croton-on-Hudson, NY: North River Press.

Goldratt E. M. (1988). Computerized shop floor scheduling. The International Journal of Production Research, 26 (3), pp. 443-455. DOI: $\underline{10.1080 / 00207548808947875}$

Goldratt E. M., Cox J. (1984) The Goal. New York: NorthRiver Press.

Goldratt E. M., Fox R. E. (1986) The Race. New York: NorthRiver Press.

Goldratt R., Weiss N. (2005) Significant enhancement of academic achievement through application of the Theory of Constraints (TOC). Human Systems Management, 24 (1), pp. 13-19.

Grönroos C. (2007) Service management and marketing: customer management in service competition. John Wiley \& Sons.

Gupta M., Kline J. (2008) Managing a community mental health agency: a theory of constraints based framework. Total Quality Management, 19 (3), pp. 281-294. DOI: $10.1080 / 14783360701601850$

Honohan P. (2000) Consequences for Greece and Portugal of the opening-up of the European banking market. The internationalization of financial services: Issues and lessons for developing countries. The Hague: Kluwer Law International.

Jacobs F. R. (1983) The OPT scheduling system: a review of a new production scheduling system. Production and Inventory Management, 24 (3), pp. 47-51.

Kotler P., Armstrong G., Saunders J., Wong V. (1986) Principles of Marketing (3rd Ed). FT Prentice Hall.

Ku E. K. C. (2007) An Investigation of Theory of Constraints (TOC) and Related Techniques in Health Care Operations. Doctoral dissertation, University of Nottingham.

Lopes J. M. G. (2001) Direito Bancário Institucional. Lisboa: Vislis.

López I. D. L., Arbeláez J. U. Castaño, D. N. (2006) Aplicación de la Teoría de Restricciones (TOC) a la gestión de facturación de las Empresas Sociales del Estado, ESE.: Una contribución al Sistema de Seguridad Social en Colombia, Innovar, 16 (27), pp. 91 -100.

Lubitsh G., Doyle C., Valentine J. (2005) The impact of theory of constraints (TOC) in an NHS trust. Journal of Management Development, 24 (2), pp. 116-131. DOI: $\underline{10.1108 / 02621710510579482}$

Mabin V. J., Balderstone S. J. (2003) The Performance of the Theory of Constraints Methodology: Analysis and Discussion of Successful TOC Applications. International Journal of Operations and Production Management, 23(6), pp. 568-595. DOI: $10.1108 / 01443570310476636$ 
Martins E. F. (2006) Marketing Relacional na Banca. A Fidelização e a Venda Cruzada. Porto: Vida Económica.

Motwani J., Vogelsang K. (1996) The theory of constraints in practice - at Quality Engineering, Managing Service Quality, 6 (6), pp. 43-47.

Motwani J., Klein D., Harowitz R. (1996a) The Theory of Constraints in Services: Part 1 - the Basics. Managing Service Quality, 6 (1), pp. 53-56.

DOI: $10.1108 / 09604529610108162$

Motwani J., Klein D., Harowitz, R. (1996b) The Theory of Constraints in Services: Part 2 - Examples from Health Care. Managing Service Quality, 6(2), pp. 30-34.

DOI: $\underline{10.1108 / 09604529610109738}$

OCDE (2005) Annual Report. Paris: The Organisation for Economic Co-operation and Development.

Olson C. T. (1998) The theory of constraints: application to a service firm. Production and Inventory Management Journal, 39, pp. 55-59.

Parasuraman A., Zeithaml V. A., Berry L. L. (1985) A conceptual model of service quality and its implications for future research. The Journal of Marketing, 49 (4), pp. 41-50. DOI: $\underline{10.2307 / 1251430}$

Rahman S. U. (1998) Theory of constraints: a review of the philosophy and its applications. International Journal of Operations \& Production Management, 18 (4), pp. 336-355.

Ramachandran A., Chidambaram, V. (2012) A review of customer satisfaction towards service quality of banking sector. Periodica Polytechnica Social and Management Sciences, 20 (2), pp. 71-79. DOI: $10.3311 /$ pp.so.2012-2.02

Reid R. A. (2007) Applying the TOC five-step focusing process in the service sector: A banking subsystem. Managing Service Quality, 17( 2), pp. 209-234.

DOI: $\underline{10.1108 / 09604520710735209}$

Reid R. A., Cormier J. R. (2003) Applying the TOC TP: a case study in the service sector. Managing Service Quality, 13 (9), pp. 349-369. DOI: $10.1108 / 09604520310495831$

Ritson N., Waterfield N. (2005) Managing change: the theory of constraints in the mental health service. Strategic Change, 14 (8), pp. 449-458. DOI: $10.1002 /$ isc. 745

Rubalcaba L. (2007) The new service economy: Challenges and policy implications for Europe. Edward Elgar Publishing.
Salgado R. J. S. (2011) Banking Concentration in the European Union during the Last Fifteen Years. Panoeconomicus, 58(2), 245-266. DOI: $10.2298 /$ pan $1102245 \mathrm{~s}$

Saunders M. N. K., Lewis P., Thornhill A. (2003) Research methods for business students (3rd Ed). Harlow: FT Prentice Hall.

Schmenner R. W. (1986) How can service businesses survive and prosper. Sloan Management Review, 27(3), 21-32.

Shoemaker T. E., Reid R. A. (2005) Applying the TOC thinking process: a case study in the government sector. Human Systems Management, 24 (1), pp. 21-37.

Shostack G. L. (1977) Breaking free from product marketing. Journal of Marketing, 41 (2), pp. 73-80. DOI: $10.2307 / 1250637$

Sina S. (1999) A classified model for applying the theory of constraints to service organizations. Managing Service Quality, 9 (4), pp. 255-264. DOI: $\underline{10.1108 / 09604529910273201}$

Spencer M. S. (2000) Theory of constraints in a service application: the Swine Graphics case. International Journal of Production Research, 38 (5), pp. 1101-1108. DOI: $\underline{10.1080 / 002075400189040}$

Spencer M. S., Wathen,S. (1994). Applying the theory of constraints' process management technique to an administrative function at Stanley Furniture. National Productivity Review, 13 (3), pp. 379-385. DOI: $\underline{10.1002 / n p r .4040130309}$

Tanner Jr. J. F., Honeycutt Jr. E. D. (1996) Reengineering using the theory of constraints: A case analysis of Moore Business Forms. Industrial Marketing Management, 25 (4), pp. 311-319. DOI: $\underline{\text { 10.1016/0019-8501(96)00029-6 }}$

Taylor, L. J., \& Thomas, E. E. (2008). Applying Goldratt's thinking process and the theory of constraints to the invoicing system of an oil and gas engineering consulting firm. Performance Improvement, 47 (9), pp. 26-34. DOI: $10.1002 / \mathrm{pfi} .20031$

UNCTAD World Investment Report- Transnational Corporations, Agricultural Production and Development. New York and Génova: United Nations Conference on Trade and Development (2011).

Zeithaml V. A., Bitner M. J. (1996) Service marketing. New York, NY: McGraw-Hill. 